\title{
RAGAM BAHASA WARIA DI KOTA BALIKPAPAN
}

\author{
Rahmawati Prihatini ${ }^{1}$, Rika Istianingrum ${ }^{2}$, Maryatin $^{3}$ \\ Universitas Balikpapan ${ }^{1}$, Universitas Balikpapan ${ }^{2}$, Universitas Balikpapan ${ }^{3}$ \\ Pos-el: nengrhama24@gmail.com¹, rika@uniba-bpn.ac.id², maryatin@uniba-bpn.ac.id³
}

\begin{abstract}
ABSTRAK
Bahasa binan/waria merupakan salah satu bagian dalam bahasa slang. Penelitian ini bertujuan untuk mendeskripsikan bentuk kosakata bahasa waria/ binan di kota Balikpapan serta mengetahui faktor yang mempengaruhi penggunaan bahasa waria/binan di Balikpapan. Penelitian ini merupakan penelitian kualitatif. Data penelitian berupa kata, kalimat, dialog bahasa binan. Sumber data penelitian yaitu waria di salon WN dan waria di daerah Markoni dan Dusit. Pengumpulan data dilakukan dengan studi lapangan menggunakan metode simak, catat, dan rekam. Instrumen penelitian yang digunakan berupa handphone untuk merekam data. Data dianalisis dengan menggunakan metode padan. Pemeriksaan keabsahan data berupa triangulasi sumber, metode, dan teori. Hasil penelitian menunjukkan bahwa penggunaan bentuk -ong dan manasuka lebih banyak digunakan oleh para waria saat ini. Selanjutnya faktor- faktor yang mempengaruhi penggunaan bahasa binan di kota Balikpapan diantaranya (1) lajunya arus urbanisasi di kota Balikpapan tahun 2016, (2) penggunaan bahasa binan sebagai identitas diri kaum waria, (3) penggunaan bahasa binan disebabkan oleh lingkungan, dan (4) penggunaan bahasa binan yang menjadi bahasa gaul di masyarakat.
\end{abstract}

Kata Kunci: ragam bahasa, bahasa binan, dan waria

\begin{abstract}
The binan/transgender language is one part of the slang language. This study aims to describe the vocabulary form of waria/binan language in the city of Balikpapan and to know the factor that influence the use of transsexual/binan language in Balikpapan. This research is a qualitative research. Research data in the form of words, sentences, language dialogue binan. Sources of research data are transvestites in the salon WN and transvestites in the area Markoni and Dusit. Data collection was done by field study using the method of referring, record, and record. Research instrument used in the form of mobile phone to record data. Data were analyzed by using method of padan. The validity of data in the form of triangulation of sources, methods, and theory. The results showed that the use of forms and manasuka more widely used by transvestites today. Furthermore, factors affecting the use of binan language in Balikpapan are: (1) the speed of urbanization in Balikpapan city 2016, (2) the use of binan language as the identity of transvestites, (3) the use of binan language is caused by the environment, and (4)) the use of binan language that became slang language in the community
\end{abstract}

Keywords : variety of languages, binan language, and transvestites 


\section{PENDAhuluan}

Bahasa yang digunakan dalam suatu masyarakat erat kaitannya dengan masyarakat penutur bahasa itu sendiri. Sejauh ini bahasa dalam masyarakat sangat beragam dan terus berkembang tidak hanya sebatas menggunakan bahasa baku atau resmi. Keragaman bahasa ini muncul akibat kebutuhan penutur dalam memilih bahasa sesuai dengan situasi konteks sosialnya.

Soeparno (2002: 71) menjelaskan bahwa ragam bahasa atau variasi bahasa adalah keanekaragaman bahasa yang disebabkan oleh faktor-faktor tertentu. Faktor-faktor penyebab keragaman itu terjadi diantaranya seperti faktor kronologis, geografis, faktor sosial, faktor fungsional, faktor gaya/ style, kultural, dan faktor individual.

Ragam atau variasi bahasa terbagi menjadi dua pandangan. Pertama, variasi atau ragam bahasa dilihat sebagai akibat adanya keragaman sosial penutur bahasa itu dan keragaman fungsi bahasa itu. Artinya bahasa itu terjadi sebagai akibat keragaman sosial dan keragaman fungsi bahasa. Kedua, variasi atau ragam bahasa itu sudah ada untuk memenuhi fungsinya sebagai alat interaksi dalam kegiatan masyarakat yang beraneka ragam. Variasi atau ragam bahasa itu dapat diklasifikasikan berdasarkan adanya keragaman sosial dan fungsi kegiatan di dalam masyarakat sosial.

Salah satu ragam atau variasi bahasa yang kita kenal adalah variasi sosial atau sosiolek. Variasi ini disebabkan oleh perbedaan sosiologis. Variasi ini menyangkut semua permasalahan pribadi penuturnya seperti usia, pendidikan, seks, pekerjaan, tingkat kebangsawanan, keadaan sosial ekonomi, dan sebagainya. Dalam variasi sosial yang berkenaan dengan tingkat, status, golongan, dan kelas sosial penuturnya terdapat beberapa varasi bahasa seperti akrolek, basilek, vulgar, slang, kolokial, jargon, argot, dan ken. Waria merupakan salah satu komunitas yang eksistensinya tidak diragukan di dalam masyarakat dan sebagai salah satu penyumbang dalam penggunaan variasi bahasa terbesar, bahasa-bahasa baru yang mereka ciptakan terbilang unik dan selain unik kosakatakosakata mereka susah dipahami oleh masyarakat pada umumnya. Waria termasuk dalam bagian LGBT (Lesbi, Gay, Bisekusal, Transgender dan Transeksual) yang secara biologis berkelamin laki-laki tetapi berpenampilan serta berperilaku seperti perempuan.

Chaer (2010: 67) mendeskripsikan bahwa slang adalah variasi sosial yang bersifat khusus dan rahasia. Artinya variasi ini digunakan oleh kalangan tertentu yang sangat terbatas dan tidak boleh diketahui oleh kalangan diluar kelompok itu. Oleh karena itu, kosakata yang digunakan dalam slang ini selalu berubah-ubah. Dapat disimpulkan bahwa slang merupakan variasi bahasa yang sifatnya khusus serta rahasia, karena khusus dan rahasia maka variasi bahasa ini hanya digunakan oleh komunitaskomunitas yang memang memiliki bahasa tersendiri selain itu penggunaan kosakata selalu diubah agar tetap tercipta kerahasiaan bahasanya.

Berdasarkan hasil pengamatan yang dilakukan oleh peneliti terhadap komunitas waria salon WN di kota Balikpapan, penggunaan kosakata slang waria sangatlah unik. Seperti pada kata jelong, sutra, organda, pewong, lekong dan masih banyak lagi. Pada kata jelong berasal dari kata "jelek", kata sutra berasal dari kata "sudah", organda berasal dari kata orang, pewong berasal dari kata perempuan, lekong berasal dari 
kata laki-laki. Kosakata yang diciptakan tidak semata-mata untuk merusak tata bahasa baku atau resmi, melainkan kosakata tersebut menjadi identitas diri yang membedakan komunitas waria dengan masyarakat umum. Selain itu kosakata-kosakata bahasa slang waria ini dapat dikaji secara linguistik baik dari segi fonologi, morfologi, sintaksis, bahkan makna setiap kata dan kalimat pada suatu ujarannya.

Dalam penelitian ini, peneliti memilih bahasa slang waria sebagai objek penelitian. Peneliti memilih objek tersebut karena sifat bahasa yang bersifat arbitrer sehingga memudahkan para penutur bahasa menggunakan atau menciptakan bahasa-bahasa baru sehingga kosakata-kosakata bahasa menjadi bertambah. Mengapa bahasa slang waria yang peneliti ambil karena waria merupakan suatu komunitas di dalam masyarakat yang memiliki eksistensi tersendiri, bahasa yang mereka gunakan juga terbilang sulit untuk dipahami khalayak umum, tidak dapat kita pungkiri sekarang ini bahasa slang waria sering digunakan oleh masyarakat umum tapi itu hanya beberapa kosakatakosakata saja tidak keseluruhan. Dari latar belakang tersebut peneliti tertarik melakukan penelitian dengan judul "Ragam Bahasa Waria di Kota Balikpapan”.

\section{Ragam Bahasa Binan}

Oetomo (2001: 62) menjelaskan bahwa dalam dekade 1990-an ini adalah meluasnya penggunaan ragam bahasa yang awalnya berasal dari ragam yang dipakai oleh komunitas waria dan gay (homoseks). Dengan perkataan lain, ragam bahasa yang dalam komunitas asalnya dikenal sebagai bahasa binan. Bahasa binan sebagai sosiolek dapat dikatakan sebagai bahasa subkultur yang disebut dengan bahasa khusus selain itu bahasa binan termasuk dalam kategori bahasa slang.

Chaer (2010: 67) menjelaskan bahwa slang merupakan variasi sosial yang bersifat khusus dan rahasia. Artinya variasi ini digunakan oleh kalangan tertentu yang sangat terbatas dan tidak boleh diketahui oleh kalangan di luar kelompok itu. Bahasa binan inilah yang membedakan komunitas waria dan gay (homoseks) dari orang-orang yang tergolong dalam kelompok sosial diluar mereka. Seiring berjalannya waktu bahasa binan kemudian dikenal menjadi bahasa gaul. Bahasa slang adalah hasil kombinasi kekurangwajaran bahasa dengan reaksi terhadap kosakata yang serius, kaku, muluk, megah, atau tidak menarik.

Berdasarkan pendapat di atas dapat disimpulkan bahwa bahasa binan merupakan bahasa yang digunakan oleh waria dan gay (homoseks) untuk berkomunikasi dengan komunitasnya, selain itu bahasa binan termasuk dalam kategori bahasa slang. Bahasa slang merupakan bahasa yang bersifat khusus dan rahasia. Penggunaan bahasa binan oleh komunitas waria tidak semata-mata untuk merusak kosakata bahasa baku atau resmi melainkan sebagai ciri pembeda (dengan kata lain sebagai identitas diri) komunitas waria dengan masyarakat umum.

\section{Bentuk Kosakata Bahasa Binan}

Kosakata bahasa binan dibentuk dengan dua proses, yakni proses perubahan bunyi dalam kata yang berasal dari bahasa daerah atau bahasa Indonesia dan proses penciptaan kata atau istilah baru ataupun penggeseran makna kata atau istilah (plesetan) yang sudah ada dalam bahasa daerah atau bahasa Indonesia. Sejauh ini kita ketahui, di 
Indonesia ini tercatat ada enam jenis proses pembentukan kata-kata bahasa binan. Oetomo (2001: 63) memaparkan proses pembentukan kata-kata bahasa binan seperti berikut:

1. Bentuk si-

Jenis pertama ditemui di Surabaya, Malang, Semarang, Solo, Yogyakarta dan kota-kota berbasis budaya jawa lainnya, dan umumnya berupa perubahan bunyi terhadap kata-kata bahasa jawa. Proses pembentukannya:

a. berasal dari suatu kata dasar hanya suku kata pertamanya yang dipertahankan,

b. bilamana suku kata pertama berakhir dengan vokal, maka konsonan pertama suku kata berikutnya dipertahankan pula,

c. kemudian pada awal potongan itu ditambahkan awalan si-.

Contohnya: banci ban

siban, homo hom sihom.

2. Bentuk-ong dan -es

Jenis kedua dan ketiga ditemui disemua kota di Indonesia pada kalangan yang terpengaruh bahasa Indonesia Jakarta. Jenis kedua biasa dinamakan omong cong atau bahasa ong-ong, sedangkan jenis ketiga biasa dinamakan omong ces atau bahasa es-es. Proses pembentukannya:

a. mengubah suku kata terakhir sehingga berakhir dengan ong (jenis kedua) atau -es (jenis ketiga)

b. mengubah bunyi/huruf vokal suku kata sebelumnya dengan $e$ - (diucapkan [-é-].

Contohnya: laki lekong

[lékong] atau lekes [lékes], banci bencong [béncong] atau bences [bénces]. Catatan: penggunaan jenis -ong ataupun - es tidak mengikuti suatu kaidah yang pasti, terkesan orang menggunakannya secara manasuka atau sembarang.

3. Bentuk -in

Jenis keempat tampaknya hanya dipakai di Jakarta dan Bandung, setidaknya pada awalnya namun dalam perkembangannya juga menyebar ke kota-kota lain, proses pembentukannya:

a. penyisipan -in sesudah konsonan awal suku katasuku kata pada kata tertentu, sehingga kata menjadi dua kali lebih panjang

b. kemudian kata yang panjang itu dipendekkan lagi.

Contohnya: bule binuline binul, lesbi linesbini lines.

4. Bentuk -se

Jenis kelima mirip dengan jenis pertama, proses pembentukannya:

a. yaitu kata asal dipotong sehingga hanya tinggal suku kata pertama dan (kalau suku kata pertama berakhir dengan vokal) konsonan pertama suku kata berikutnya

b. kemudian ditambahkan akhiran -se'.

Contohnya: homo hom homse', cina cin cinse'.

5. Bentuk manasuka

Jenis keenam berawal dari Medan dan kemudian menyebar di semua kota-kota Indonesia. Proses pembentukannya:

a. pemertahanan suku kata atau bagian suku kata awal kata dasar, 
b. kemudian selebihnya diubah sehingga seakan-akan menjadi kata lain. Contohnya: enak en endang, sudah su sutra, tidak ti tinta, sundal sund sundari. Catatan: jenis inilah yang pada dekade

1990-an amat populer, berkembang pesat dan meluas di seluruh Indonesia dan dipakai sebagai bahasa gaul.

\section{METODE PENELITIAN}

Jenis penelitian yang digunakan yaitu penelitian kualitatif. Sugiyono (2015: 15) menjelaskan bahwa penelitian kualitatif adalah penelitian yang berlandaskan pada filsafat postpositivisme (memandang realitas/gejala/fenomena), digunakan untuk meneliti kondisi obyek yang alamiah dimana peneliti adalah sebagai instrument kunci. Metode yang digunakan pada penelitian ini adalah metode deskripsi, dimana metode ini merupakan tata cara menggambarkan data-data penelitian. Pendekatan penelitian yang digunakan peneliti adalah pendekatan sosiolinguistik.

Chaer (2010: 2) sosiolinguistik merupakan ilmu antardisiplin antara sosiologi dan linguistik. Adapun sumber data primer yang digunakan dalam penelitian ini yaitu komunitas waria di kota Balikpapan. Komunitas waria yang peneliti pilih untuk dijadikan objek penelitian yaitu waria di salon WN yang berjumlah 4 orang dan waria di daerah Markoni dan Dusit yang berjumlah 6 orang. Sumber data sekunder adalah data yang diperoleh secara tidak langsung oleh peneliti, tapi telah berjenjang melalui tangan kedua dan ketiga. Data sekunder dikenal sebagai data pendukung dan pelengkap utama yang dapat digunakan oleh peneliti. Adapun sumber data sekunder penelitian ini berupa data- data artikel, jurnal, buku referensi, dan penelitian yang relevan. Dalam penelitian ini, data yang digunakan berupa kata, kalimat, dialog bahasa binan waria di kota Balikpapan sesuai dengan rumusan masalah penelitian di salon WN dan daerah Markoni dan Dusit.

Dalam penelitian ini, instrumen utamanya adalah peneliti sendiri, namun setelah fokus penelitian menjadi jelas maka akan dikembangkan instrumen penelitian sederhana, yang diharapakan dapat melengkapi data dan membandingkan dengan data yang telah ditemukan melalui observasi dan wawancara. Untuk mempermudah penelitian yang akan dilakukan, peneliti menggunakan handphone untuk merekam data yang dibutuhkan oleh peneliti serta menggunakan kartu data untuk memisahkan data-data yang telah di dapatkan.

Moleong (2014: 126) menjelaskan bahwa pada tahap- tahap penelitian kualitatif salah satu ciri pokoknya yaitu peneliti menjadi alat penelitian. Khususnya pada analisis data ciri khasnya sudah dimulai sejak awal pengumpulan data. Bogdan (1972) membagi tahapan penelitian menjadi tiga bagian diantaranya (1) pra- lapangan, (2) kegiatan lapangan, dan (3) analisis intensif. Pada penelitian ini akan dipaparkan tahap- tahap penelitian yang dilakukan oleh peneliti dari tahap pralapangan hingga tahap analisis intensif sebagai berikut.

1. Tahap Pra- Lapangan Pada tahap pra- lapangan, peneliti memiliki beberapa tahapan- tahapan kegiatan diantaranya yaitu:

a. Menyusun Rancangan Penelitian 
Pada tahap ini peneliti sebelum melakukan penelitian telah mempersiapkan rancangan penelitian seperti menentukan metode dan teknik penelitian yang akan digunakan.

b. Memilih Lapangan Penelitian

Pada tahap ini peneliti dalam menentukan lapangan penelitian dengan jalan mempertimbangankan teori substantif dan dengan mempelajari serta mendalami fokus serta rumusan masalah penelitian. Sebaiknya keterbatasan waktu, biaya, dan tenaga perlu dipertimbangkan.

c. Menjajaki dan Menilai Lapangan

Sebelum memasuki lapangan penelitian yang sebenarnya untuk mencari data, peneliti harus memahami bagaimana situasi dan kondisi lapangan penelitian tersebut. Tahap ini merupakan tahapan orientasi lapangan dimana peneliti hanya melakukan pengamatan dan juga menilai keadaan lapangan dalam halhal tertentu.

d. Memilih dan Memanfaatkan Informan

Informan merupakan orang yang dimanfaatkan untuk memberikan informasi tentang situasi dan kondisi latar penelitian. Pada saat memilih informan peneliti tidak bisa sembarangan memilih orang- orang tersebut, peneliti harus memiliki kriteria- kriteria untuk orang- orang yang akan dijadikan informannya.

e. Menyiapkan Perlengkapan Penelitian

Tahap ini peneliti harus mempersiapkan perlengkapan penelitian baik secara moril dan meteriil. Selain perlengkapan fisik peneliti sendiri yang dipersiapakan, peneliti juga mempersiapkan alat- alat yang akan digunakan sesuai dengan kebutuhan penelitian.

2. Tahap Kegiatan Lapangan

Memasuki kegiatan lapangan, peneliti dalam hal ini harus mempersiapkan dirinya bertemu dengan informan atau narasumber penelitiannya untuk mendapatkan data penelitian yang dibutuhkan. Untuk itu sebagai seorang peneliti harus memperhatikan penampilannya, menjaga sopan dan santun, bisa menjalani sebuah hubungan yang baik dengan para informannya. Tidak hanya berperan serta dalam lingkungan tersebut peneliti tetap harus mengumpulkan data- data penelitiannya dengan mencatatnya atau merekam percakapan informan.

3. Tahap Analisis Data

Tahapan ini peneliti menganalisis data- data yang telah didapatkan berdasarkan hasil dari informasi informan. Selain menganalisis data peneliti juga melakukan intepretasi terhadap data- data tersebut untuk memperoleh arti dan makna yang lebih mendalam dan luas terhadap haasil penelitian yang sedang dilakukan. 


\section{Teknik Pengumpulan Data Penelitian}

Penelitian ini menggunakan teknik pengumpulan data berupa studi lapangan dengan menggunakan metode simak. Mahsun (2014: 92) metode simak merupakan metode atau cara yang digunakan untuk memperoleh data dilakukan dengan menyimak penggunaan bahasa. Istilah menyimak di sini tidak hanya berkaitan dengan penggunaan bahasa secara lisan, tetapi juga penggunaan secara tertulis.

Data lisan dikumpulkan dengan metode simak yang dibantu dengan teknik dasar yang berwujud teknik sadap. Selanjutnya peneliti menggunakan teknik simak libat cakap, teknik catat dan rekam sebagai teknik lanjutannya. Teknik sadap digunakan untuk menyadap kosakatakosakata bahasa binan pada komunitas waria di kota Balikpapan, kemudian teknik simak libat cakap dilakukan dengan menyimak serta berpartisipasi dalam pembicaraan. Peneliti terlibat langsung dalam dialog baik secara aktif maupun reseptif. Aktif artinya peneliti ikut berbicara dalam dialog sedangkan reseptif artinya hanya mendengarkan pembicaraan informan. Peneliti berdialog sambil menyimak pemakaian bahasa informan untuk mendapatkan kosakatakosakata bahasa binan waria. Saat penerapan teknik simak libat cakap juga disertai teknik rekam, yaitu merekam dialog atau percakapan informan. Rekaman ini selanjutnya ditranskripsikan dengan teknik catat.

\section{Teknik Analisis Data Penelitian}

Tahapan analisis data merupakan tahapan yang sangat menentukan, karena pada tahapan ini kaidah-kaidah yang mengatur keberadaan objek penelitian harus sudah diperoleh. Dalam menganalisis data pada penelitian ini menggunakan metode padan. Mahsun
(2014: 117) padan merupakan kata yang bersinonim dengan kata banding dan sesuatu yang dibandingkan mengandung makna adanya keterhubungan sehingga padan disini diartikan sebagai hal menghubung-bandingkan.

Metode padan intralingual adalah metode analisis dengan cara menghubung-bandingkan unsur-unsur yang bersifat lingual, baik yang terdapat dalam satu bahasa maupun dalam beberapa bahasa yang berbeda. Dalam pelaksanaan penelitian yang sesungguhnya, penerapan metode ini dalam tahap analisis data hanya dimungkinkan jika data yang akan dihubungbandingkan telah tersedia. Oleh karena itu tahapan penyediaan bahan (data) dalam penelitian (bahasa) memainkan peran yang sangat penting, dalam arti kelengkapan data yang menggambarkan semua kemungkinan keberadaan objek penelitian harus telah tersedia. Metode ini selain dapat digunakan untuk menganalisis unsur lingual yang terdapat dalam bahasa yang sama, juga dapat digunakan untuk menganalisis unsur lingual yang terdapat dalam bahasa yang berbeda.

Pada penelitian ini analisis data selama di lapangan ditunjang dengan menggunakan model Miles and Huberman. Miles and Huberman ( Sugiyono 2015: 337) menjelaskan bahwa aktivitas dalam analisis data kualitatif dilakukan secara interaktif dan berlangsung secara terus menerus sampai tuntas, sehingga datanya sudah jenuh. Aktivitas dalam analisis data dipaparkan sebagai berikut.

1. Reduksi Data

Data-data yang diperoleh dari lapangan jumlahnya cukup banyak perlu dicatat secara teliti dan rinci. Mereduksi data berarti merangkum, memilih hal-hal 


\begin{tabular}{|c|l|c|}
\hline No & $\begin{array}{l}\text { Bentuk Kosakata } \\
\text { Bahasa Binan }\end{array}$ & Jumlah \\
\hline 1 & Bentuk si- $^{-}$ & 2 \\
\hline 2 & Bentuk -ong & 16 \\
\hline 3 & Bentuk -es & 5 \\
\hline 4 & Bentuk -in & 3 \\
\hline 5 & Bentuk -se' & 1 \\
\hline 6 & $\begin{array}{l}\text { Bentuk } \\
\text { manasuka }\end{array}$ & 53 \\
\hline & Jumlah & 80 \\
\hline
\end{tabular}

Selain hasil yang berupa deskripsi data bentuk kosakata bahasa binan, peneliti menemukan beberapa faktor yang mempengaruhi penggunaan bahasa binan di kota Balikpapan, diantaranya sebagai berikut.

1. Lajunya pertumbuhan arus urbanisasi di kota Balikpapan pada tahun 2016.

2. Bahasa binan digunakan sebagai identitas diri kaum homoseks seperti waria.

3. Penggunaan bahasa binan oleh kaum waria dikarenakan oleh lingkungan.

4. Penggunaan bahasa binan yang menjadi bahasa gaul di dalam masyarakat.

Setelah didapatkan hasil berdasarkan dua rumusan masalah penelitian. selanjutnya hasil penelitian akan dipaparkan pada pembahasan berikut.

Pembahasan penelitian yang pertama adalah bentuk kosakata bahasa binan di kota Balikpapan. Pembahasan ini dilakukan sebagaimana pengelompokkan bentuk kosakata bahasa binan yang terdiri atas bentuk $s i$-, bentuk -ong, bentuk -es, bentuk -in, bentuk -se', dan bentuk manasuka.
Bentuk si- merupakan bentuk kosakata bahasa binan yang proses pembentukkannya berupa perubahan bunyi terhadap kata-kata bahasa Jawa pada umumnya dan tidak menutup kemungkinan katakata dalam bahasa Indonesia juga mendapatkan perubahan. Selanjutnya kata- kata tersebut mendapatkan awalan si, contohnya seperti kata siwed, sihom, siban, dan silan. Sepert pada data di bawah ini.

(1/si/1) Kamu laki tapi rasanya kayak siban.

Data (1/si/1) menggambarkan bahwa pada kalimat tersebut sesorang sedang berbicara kepada seseorang lelaki. Ia menegur lakilaki itu, dengan mengatakan kamu lelaki tetapi seperti seorang siban dalam arti lain laki-laki itu seperti banci, terlihat keperempuanperempuanan. Pada situasi ini seseorang itu hanya mengeluarkan candaan kepada lelaki itu, tidak mengatakan dengan sungguhsungguh bahwa lelaki itu seperti seorang banci.

Berdasarkan kalimat pada data (1/si/1) kosakata bahasa binan bentuk si- terdapat dalam kata siban. Siban berasal dari kata dasar banci, kata tersebut mendapatkan penambahan bentukkan si-. Prosesnya kata dasar banci dipertahankan suku kata pertamanya, secara ringkas dapat dilihat pembentukan kata siban sebagai berikut: banci ban $s i+$ ban = siban.

\section{Bentuk si-}

\section{Bentuk-ong}


Bentuk -ong merupakan bentuk kosakata bahasa binan yang proses perubahannya dengan mengubah suku kata terakhir sehingga berakhiran dengan -ong dan mengubah bunyi/ huruf vokal suku kata dengan 'e', bentuk ini tidak mengikuti suatu kaidah yang pasti terkesan orang-orang menggunakannya secara manasuka atau sembarang. Contohnya seperti pewong, lekong. bencong, dewong, dan lain sebagainya. Seperti pada data di bawah ini.

\section{(3/ong/3) Laki itu laksana atau nda lekong}

Data (3/ong/3) menggambarkan bahwa pada kalimat tersebut seseorang sedang menjelaskan kepada seseorang yang lain mengenai penggunaan atau penyebutan laki-laki di daerah Sulawesi dan di Balikpapan berbeda walaupun kata-kata itu sifatnya nasional (dipakai disetiap daerah), penyebutan untuk laki-laki di daerah Sulawesi menggunakan kata laksana sedangkan di kota Balikpapan penyebutan untuk laki-laki menggunakan kata lekong.

Berdasarkan data (3/ong/3) dapat kita lihat kosakata bahasa binan bentuk -ong yang terdapat pada kata lekong yang berasal dari kata laki. Prosesnya pembentukan kata-kata tersebut yaitu dengan mengubah suku kata terakhir, kemudian ditambahkan akhiran -ong dan mengubah bunyi/huruf vokal suku kata a dengan $e$ - (diucapkan -é). Secara ringkas dapat dilihat pembentukan kata lekong sebagai berikut: Laki lak (vokal 'a' dirubah menjadi vokal 'e/é') lek + ong = lekong atau lékong.

Bentuk -es merupakan bentuk kosakata bahasa binan yang proses perubahannya dengan mengubah suku kata terakhir sehingga berakhiran dengan -es dan mengubah bunyi/ huruf vokal suku kata dengan 'e', bentuk ini tidak mengikuti suatu kaidah yang pasti terkesan orang-orang menggunakannya secara manasuka atau sembarang. Contohnya seperti bences, lekes, dan lain sebagainya. Seperti pada data di bawah ini.

(19/es/3) Eike tau say dékes yang bagus buat pasang gituan biar banyak tamara yang datang ke kita.

Data (19/es/3) menggambarkan bahwa pada kalimat di atas seseorang sedang berbincang dengan orang lain. Dia memberitahukan kepada temannya dimana dukun yang bagus buat pasang susuk. Dapat kita lihat pada kutipan "eike tau say dékes yang bagus buat pasang gituan". Kata 'gituan' merujuk pada arti susuk. Selanjutnya dia juga menegaskan kepada temannya setelah pasang susuk di dukun itu jadi banyak tamu yang datang ke kita, dapat dilihat dalam kutipan "biar banyak tamara yang datang ke kita".

Berdasarkan data (19/es/3) dapat kita lihat kosakata bahasa binan bentuk -es terdapat pada kata dékes. Kata dékes berasal dari kata dukun. Proses pembentukkannya yaitu dengan mengubah suku kata terakhir dengan -es dan mengubah bunyi/ huruf vokal dengan 'e/é). Secara singkat dapat dilihat proses 
pembentukkannya seperti berikut: dukun duk (terjadi perubahan vokal 'u' menjadi vokal e/é pada kata 'duk') dek $+e s=$ dekes atau dékes.

\section{Bentuk-in}

Bentuk -in merupakan bentuk kosakata bahasa binan yang prosesnya menyisipkan sisipan -insesudah konsonan awal sukukata pada kata tertentu, sehingga kata tersebut menjadi panjang kemudian kata yang panjang itu dihilangkan bagian suku kata terakhir. Contohnya seperti kata lines, binul, dan lainnya. Seperti pada data di bawah ini.

(24/in/2) kemes ini kesukaannya binul say, pasti banyak yang mau, kan bule bule suka kulitnya yang coklat coklat gini.

Data (24/in/2) menggambarkan bahwa pada kalimat di atas seseorang sedang berbincang dengan orang lain di salon. Dia memberitahukan kepada orang tersebut, bahwa orang asing (bule) menyukai seseorang berkulit coklat sawo matang, dapat kita lihat pada kutipan "kemes ini kesukaannya binul say" yang artinya kamu ini kesukaannya bule.

Berdasarkan data(24/in/2) dapat kita lihat bentuk -in terdapat pada kata binul. binul berasal dari kata bule (orang barat). Perosesnya adalah dengan penyisipan -in sesudah konsonan awal suku kata pada kata tertentu, sehingga kata menjadi dua kali lebih panjang kemudian kata itu di pendekan lagi. Secara singkat proses pembentukan kata binul dapat kita lihat seperti berikut: bule $\mathrm{b}+i n+\mathrm{ul}$ - ine binul

\section{Bentuk-se'}

Bentuk se'- merupakan bentuk kosakata bahasa binan yang proses pembentukan kata-katanya ditambahkan dengan akhiran -se', kata- kata tersebut dipertahankan suku kata pertamanya. Contohnya seperti kata homse', cinse, dan lainnya. Seperti pada data di bawah ini.

\section{$\left(27 / \mathrm{se}^{\prime} / 3\right)$ Ada say itu hari} tamaraku orang cinse', cucok say.

Data (27/se'/3) menggambarkan bahwa kalimat di atas seseorang sedang bercerita kepada orang lain yaitu temannya kalau dia pernah bersama dengan seorang tamu. Tamu tersebut orang cina, selain itu dia menegaskan lagi bahwa tamu tersebut orangnya cakep. Pada konteks ini, makna dari kalimat tersebut itu merujuk pada suatu kegiatan hubungan seks yang pernah dia lakukan.

Berdasarkan data (27/se'/3) dapat kita lihat kosakata bahasa binan bentuk -se' terdapat pada kata cinse'. Cinse' berasal dari kata Cina (merujuk pada seseorang yang memiliki darah atau keturunan Cina). Proses pembentukannya dengan mempertahankan suku kata pertama dan mengubah suku kata terakhir dengan akhiran $-s e$ '. Secara singkat dapat dilihat proses pembentukkannya seperti berikut: Cina $\operatorname{cin} \operatorname{cin}+s e^{\prime}=$ cinse'.

\section{Bentuk manasuka}

Bentuk manasuka merupakan kosakata bahasa binan yang proses pembentukannya tidak mengikuti sistematika penulisan yang ada, bentuk ini biasa digunakan secara 
suka-suka oleh para penggunanya. Pada kata-kata yang digunakan secara manasuka terjadi pemertahan bagian awal suku kata dasar selanjutnya suku kata terakhir diubah sehingga seakan-akan menjadi kata lain. Contohnya seperti kata sutra, sundari, tinta, dan lainnya. Seperti pada data di bawah ini.

\section{(28/manasuka/1) Cuman itu belum baku tapi, yang ke' kemandra, akika.}

Data

(28/manasuka/1)

menggambarkan bahwa seseorang sedang memberitahukan kepada orang lain bahwa penggunaan kata kemandra, akika oleh Debby Sahertian itu belum baku. Sebelumnya seseorang juga menjelaskan bahwa kamus bahasa gaul itu ada dijual.

Berdasarkan data (28/manasuka/1) dapat kita lihat kosakata bahasa binan bentuk manasuka terdapat pada kata kemandra. Kata kemandra berasal dari kata kemana. Prosesnya pemertahanan bagian awal suku kata, sehingga tercipta kata dasar yang berdiri sendiri, sementara suku kata lainnya diubah, sehingga menghasilkan kata lain yang berbeda dengan yang awal. Secara singkat dapat kita lihat proses pembentukan kata kemandra sebagai berikut: kemana kema kemandra.

\section{KESIMPULAN}

Berdasarkan hasil penelitian dan pembahasan pada bab sebelumnya terhadap penelitian ini, maka didapatkan kesimpulan sesuai dengan rumusan masalah yang ada. Hasil penelitian yang pertama berkaitan dengan bagaimana bentuk kosakata bahasa binan di kota Balikpapan pada tahun 2016. Setelah peneliti turun ke lapangan dan mendapatkan data yang berupa tuturan, kata, kalimat bahasa binan selanjutnya peneliti melakukan analisis dan mendeskripsikan data-data tersebut. Penemuan penggunaan kosakata bahasa binan ada enam bentukkan diantaranya bentuk si-, bentuk -ong, bentuk -es, bentuk -in, bentuk $-s e$, dan bentuk manasuka. Dari keenam bentuk tersebut, bentuk -ong dan manasuka yang paling banyak digunakan para oleh para waria ketika berkomunikasi dengan waria lainnya.

Hal ini dapat dibuktikan pada hasil penggunaan bahasa binan di kota Balikpapan tahun 2016 yang menunjukkan bentuk si- sebanyak 2 tuturan, bentuk - ong sebanyak 16 tuturan, bentuk - es sebanyak 5 tuturan, bentuk -in sebanyak 3 tuturan, bentuk -se' sebanyak 1 tuturan, dan bentuk manasuka sebanyak 53 tuturan dari keseluruhan data sebanyak 80 data tuturan.

Setelah melakukan pendeskripsian data yang didapatkan, barulah peneliti mendapatkan jawaban mengapa bentuk manasuka dan -ong lebih banyak digunakan. Penggunaan kosakata bentuk -ong dan manasuka yang mendominasi kosakata- kosakata bahasa binan saat ini dikarenakan oleh beberapa faktor diantaranya: 1) bentuk -ong dan manasuka tidak mengikuti suatu kaidah/ aturan yang pasti, terkesan penggunaannya terbilang manasuka atau sembarang. 2) kata- kata yang sering diplesetkan oleh para waria menyebabkan terciptanya kosakata- kosakata baru

Penelitian ini tidak hanya menampilkan hasil yang berupa deskripsi bentuk kosakata bahasa binan, melainkan peneliti juga menemukan beberapa faktor yang mempengaruhi penggunaan bahasa 
binan di kota Balikpapan diantaranya sebagai berikut: (1) lajunya arus urbanisasi di kota Balikpapan pada tahun 2016, (2) penggunaan bahasa binan sebagai identitas diri kaum waria, (3) penggunaan bahasa binan oleh kaum waria dikarenakan oleh lingkungan, dan (4) penggunaan bahasa binan yang menjadi bahasa gaul di dalam masyarakat.

Berdasarkan keempat faktor diatas dapat ditarik kesimpulan bahwa penggunaan bahasa binan tidak sematamata hanya dilakukan oleh para waria, keadaan lingkungan dan masyarakat umum juga dapat turut serta dalam penyebaran atau penggunaan bahasa binan itu sendiri. Selain itu bahasa binan telah menjadi bagian dalam bahasa gaul, yang saat ini ke populerannya tidak dipungkiri baik dikalangan yang muda, remaja, anak-anak, dan orang tua.

\section{DAFTAR PUSTAKA}

Chaer, Abdul dan Leoni Agustina. (2010). Sosiolinguistik Perkenalan Awal. Jakarta: PT Rineka Cipta.

Mahsun. (2014). Metode Penelitian Bahasa Tahapan strategi, metode, dan tekniknya. Jakarta: PT Raja Grafindo Persada.

Moleong, Lexy J. (2014). Metode Penelitian Kualitatif. Bandung: PT Remaja Rosdakarya

Oetomo, Dede. (2001). Memberi Suara Pada Yang Bisu. Yogyakarta: Galang Press

Soeparno. (2002). Dasar-Dasar Linguistik Umum. Yogyakarta: PT Tiara Wacana Yogya

Sugiyono. (2015). Metode Penelitian Pendidikan Pendekatan Kuantitatif,

Kualitatif, dan $R \& D$. Bandung: Alfabeta 